\title{
EFFECT OF PROPAGATION METHODS AND ORGANIC FERTILIZATION ON GROWTH AND CHEMICAL CONSTITUENTS OF OCIMUM BASILICUM L.,' SWEET BASIL.'
}

Faisal M.A. Matter ${ }^{1}$ and Essam G. Somida ${ }^{2}$

1- Dep. of Hort. Fac. of Agric., Fayoum Univ., Egypt

2- Dep. of Hort., Ministry of Education Egypt

\section{ABSTRACT}

Two filed experiments were carried out during the two successive years of 2004 and 2005) to study the effect of propagation methods (seedlings from seeds and terminal cuttings) alone or with using organic manure fertilizer such as farm yard manure "FYM" or poultry manure "PM" at rates $0,10,20$ and 30 $\mathrm{m}^{3} /$ fed. on growth and chemical constituents of sweet basil plants. The obtained results indicated that, all growth parameters i.e., plant height, number of branches/plant, number of inflorescences/plant, fresh weight of herb/plant and number of roots as well as volatile oil percentage, oil yield per plant and per feddan, $\mathrm{N}, \mathrm{P}$ and $\mathrm{K} \%$ and total carbohydrate contents in the herb were significantly increased as methods of propagation such as terminal cuttings and organic manure application of poultry manure. The best results were obtained from poultry manure at rate of $20 \mathrm{~m}^{3} / \mathrm{fed}$. or farm yard manure at rate of $30 \mathrm{~m}^{3} / \mathrm{fed}$. Also cultivate terminal cuttings combined with organic manure fertilization gave the best results than seedlings combined with organic manure fertilization. Terminal cuttings combined with poultry manure gave the best results than other combines. The maximum increment in the studied growth parameters and chemical constituents as well as yield and its component were obtained by cultivate with terminal cuttings using medium rate 20 $\mathrm{m}^{3} /$ fed. from poultry manure or high rate $30 \mathrm{~m}^{3} / \mathrm{fed}$. from farm yard manure at rate of $30 \mathrm{~m}^{3} / \mathrm{fed}$. fertilization.

Key words: Sweet basil (Ocimum basilicum L.) propagation methods (seedlings and terminal cuttings) and organic manure, farm yard manure "FYM", poultry manure "PM", growth parameters and chemical constituents.

\section{INTRODUCTION}

Sweet basil (Ocimum basilicum L.) is a popular aromatic and medicinal plant of Lamiaceae and is well known for its highly aromatic leaves used either fresh or dried and for culinary of the 150 species of Ocimum basilicum L. It is most important species being utilized as a source of essential oil (Hussein et al., 1988). Basil can be grown from seeds or cuttings; this is particularly helpful for preserving the integrity of unusual varieties. Several basil species have antimicrobial and antifungal properties (Blumenthal, 1998 and Opalchenova and Obreshkova. 2003) and anti-cancer properties (Aruna and Sivaramakrishnan, 1992). It is also used as an ingredient of coughrelieving, stomachache, diuretic, carminative tea blends and can lower blood sugar levels and aid "insulin release (Nyarko, 2002). It is used in food industries for spicing canned drinks (Hornok, 1992). Essential oil that used in

Fayoum J. Agric. Res. \& Dev., Vol. 20, No. 2, July, 2006 
manufacturing perfumes, soaps and shampoos. (Ocimum basilicum L.var. difform Benth) is one of the introduced varieties, have been cultivate in a private farm in Sennouris, Fayoum Governorate, for obtained the high yield of Ocimum basilicum L. and neutral production to keep our healthy and animal health we must cultivate using terminal cuttings and faraway from the comical cultural or used at least smallest amount of it, as well as organic cultural. The organic matter content of Egyptian soil is usually less than $2 \%$ in cultivate area. Frequent and high application of organic manure are necessary to maintain soil fertility and to provide the growing plants with their nutritional requirements without having an undesirable impact on the environment, organic fertilization also provides a means for alleviating the problem of chemical residues in the exporting market.

Abd El-Raouf (2001) found that increasing organic fertilization level as compost due to increasing the plant height, number of branches/plant, number of inflorescences/plant, fresh weight/plant and volatile oil percentage, yield in the herb per plant and per feddan of sweet basil.

El-Gendy et al., (2001) reported that, the treated sweet basil plants with organic manure as compost at rates $15,25,35,45,55$ and $65 \mathrm{~m}^{3} / \mathrm{fed}$. caused to increases in growth characters/plant i.e., plant height, number of branches, and herb fresh weights and volatile oil percentage, yield in the herb per plant and per feddan.

Matter and Mohamed (2001) on Calendula officinalis L. plants investigated the effect of farmyard manure or poultry manure application and found that the plant height, number of branches, dry weight of shoots/plant, number of inflorescences/plant, pigment content, $\mathrm{N}, \mathrm{P}$ and $\mathrm{K}$ and total carbohydrates were significantly increased by increasing the rates from 0 to $200 \mathrm{~g} / \mathrm{pot}$ for the two organic types, and found that poultry manure gave the best result than farmyard manure

Mohamed and Matter (2001) showed that the poultry manure and farmyard manure at rates $(0,4$ and $8 \mathrm{t} / \mathrm{fed}$.) on Tagetes minuta L. significantly increased the plant height, number of branches/plant, fresh of shoots, number of inflorescences, chlorophyll a ,b and caroteniods, volatile oil percentage, yield in the herb per plant and per feddan and $\mathrm{N}, \mathrm{P}, \mathrm{K}$. The best effect in this respect was obtained by poultry manure.

Sakr (2001) on Mentha piperita L. plants studied the effect of organic manure at rates, 5,10 and $20 \mathrm{~m}^{3} / \mathrm{fed}$. as poultry, 10,20 and $40 \mathrm{~m}^{3} / \mathrm{fed}$. as cattle manure and 10,20 and $30 \mathrm{~m}^{3} / \mathrm{fed}$. as sheep manure and found that, poultry manure at $20 \mathrm{~m}^{3} / \mathrm{fed}$. was statistically increased and the most efficient dose among the involved doses of the different manure fertilizers followed by sheep manure at $30 \mathrm{~m}^{3} / \mathrm{fed}$. and cattle manure at $40 \mathrm{~m}^{3} / \mathrm{fed}$. on vegetative characters chlorophyll a, b, total chlorophyll, caroteniods, N, P, K and total carbohydrates.

Somida, (2002) found that treating the Tagetes minuta plants with poultry manure at rates $4,8,12 \mathrm{~m}^{3}$ enhanced the plant height, number of branches, fresh weight of herb, number of inflorescences, volatile oil percentage and yield in the herb per plant and per feddan, chlorophyll $a, b$, caroteniods, N, P, K and total carbohydrate contents.

Adams, (2003) growing basil from cuttings is relatively easy and is important if you want to prevent crossing.

El-Yazal, et al., (2005) recorded that, poultry manure at rates of 10 and $15 \mathrm{~m}^{3}$ produced the best results from plant height, number of branches,

Fayoum J. Agric. Res. \& Dev., Vol. 20, No. 2, July, 2006 
EFFECT OF PROPAGATION METHODS AND ORGANIC

fresh weight of herb, number of inflorescences, volatile oil percentage and yield in the herb per plant and per feddan, N, P and K total carbohydrate on sweet basil.

Mohamed (2006) studied the effect of organic fertilizer sources (namely: poultry, farm yard and sheep manure) at rates 15, 20, 25 and $30 \mathrm{~m}^{3} /$ fed. on Hibiscus sabdariffia L. plants and found that, the high rate $30 \mathrm{~m}^{3} / \mathrm{fed}$. of organic was more effective. Poultry manure gave the best result and followed by farm yard and then sheep manure on this characters, plant height, number of branches/plant, number of capsules/plant, dry weight of leaves/plant, chlorophyll a, b, caroteniods, N, P, K and total carbohydrates.

This study was conducted with the aim of studying the effect of propagation methods (terminal cuttings and seedlings) alone or combined with organic manure such as farm yard manure "FYM" and poultry manure "PM" on the growth, oil yield and chemical composition of the Ocimum basilicum L. plants.

\section{MATERIAL AND METHODS}

The present investigation was carried out during the two successive seasons of 2004 and 2005 in farm in Sennouris Center, Fayoum Governorate. Seeds of Ocimum basilicum L., were obtained from the Research Center of Medicinal and Aromatic plants in Giza, Egypt in both seasons of the study. On April $1^{\text {th }}$ of each season, seeds were sown in a well prepared seed bed in the same farm. Uniform seedlings or terminal cuttings of $10 \mathrm{~cm}$ length were transplanted on May $15^{\text {th }}$ in the two seasons. Split split plot design with three replicates was used. Application methods of propagation (seedlings and terminal cuttings) were arranged in the main plots, while sources of organic manure were allocated in sub-blots and organic manure levels in sub-sub plots. The experiment comprised 16 treatments; each replicate contained one plot $(2 \times 2 \mathrm{~m})$ each plot contained 4 rows $(50 \mathrm{~cm}$ apart $)(2 \times 2 \mathrm{~m})$ and distance between plants was $30 \mathrm{~cm}$, each plot contained 28 plants.

Organic manure such as farm yard manure (FYM) or poultry manure (PM) was obtained from private farms. The chemical and physical analysis of used soil and organic fertilizers are shown in Table (1). Organic manure at the rates $0,10,20$ and $30 \mathrm{~m}^{3} / \mathrm{fed}$. were applied into two doses. The first dose was incorporated with the soil before planting about two weeks and the second dose was applied as basal dressing after the first cut.

Fayoum J. Agric. Res. \& Dev., Vol. 20, No. 2, July, 2006 
Faisal M.A. Matter and Esam G. Somida

Table (1): Chemical and physical analysis of used soil and organic fertilizers

\begin{tabular}{|c|c|c|c|c|}
\hline \multicolumn{2}{|c|}{$\begin{array}{r}\text { Properties } \\
\end{array}$} & Soil & FYM & PM \\
\hline \multicolumn{2}{|r|}{ Sand } & 20.90 & - & - \\
\hline \multicolumn{2}{|r|}{ Silt } & 32.22 & - & - \\
\hline \multicolumn{2}{|r|}{ clay } & 22.9 & - & - \\
\hline \multicolumn{2}{|r|}{ Texture grade } & Loam sand & - & - \\
\hline \multicolumn{2}{|r|}{ Organic matter\% } & 1.72 & 16.50 & 70.20 \\
\hline \multicolumn{2}{|r|}{$\mathrm{PH}$} & 7.50 & 7.50 & 6.30 \\
\hline \multicolumn{2}{|r|}{ Ec $\mathrm{mm} / \mathrm{cm}$} & 4.50 & 1.50 & 7.00 \\
\hline \multicolumn{2}{|r|}{ Total N \% } & 0.60 & 1.5 & 3.32 \\
\hline \multirow{6}{*}{ 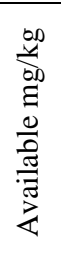 } & $\mathrm{P}$ & 25.00 & 22.00 & 38 \\
\hline & $\mathrm{K}$ & 650 & 700 & 725 \\
\hline & $\mathrm{Zn}$ & 0.73 & 11 & 160 \\
\hline & $\mathrm{Mn}$ & 2.90 & 30 & 120 \\
\hline & $\mathrm{Cu}$ & 1.26 & 4 & 22.00 \\
\hline & $\mathrm{Fe}$ & 3.62 & 146 & 1958 \\
\hline
\end{tabular}

Organic manure at the rates $0,10,20$ and $30 \mathrm{~m}^{3} /$ fed. were applied into two doses. The first dose was incorporated with the soil before planting about two weeks and the second dose was applied as basal dressing after the first cut.

Plants were treated with phosphorus at rate $200 \mathrm{~kg} / \mathrm{fed}$. in the from calcium superphosphate $15 \% \mathrm{P}_{2} \mathrm{O}_{5}$, nitrogen at rate $100 \mathrm{~kg} / \mathrm{fed}$. in urea form, and potassium sulfate $\left(48 \% \mathrm{~K}_{2} \mathrm{O}\right)$ at rate $50 \mathrm{Kg} / \mathrm{fed}$. The amount of fertilizers were divided into two equal doses and applied as basal dressing. The first dose was added after three weeks from transplanting, the second dose after three weeks from the first cut. Two cuts were taken after flowering, the first cut was taken on $15^{\text {th }}$ July and the second cut was taken on $15^{\text {th }}$ September in which plant height, number of branch, number of inflorescences, fresh weight of herb and number of roots was recorded for each replicate. Chlorophyll a, b and caroteniods (mg/100g. F.wt.) were determined in fresh leaves according to Welburn and Lichtenthaler (1984). Total carbohydrates (mg/g. D.W.) were determined colorimetric according to the method described by Herbert, et al., (1971) Nitrogen and phosphorus\% was determined according to A.O.A.C. (1995). Potassium was determined by Flame Photometer, Parkin-Elmer model 52 with acetylene burner according to Page et al., (1982). The essential oil percentage was determined in the herb according to British Pharmacopoeia method (1983) by using Clevenger apparatus for the determination of essential oil. Data were statistically analyzed according to Gomes and Gomes (1983).

Essential oil quantity (ml)

Fresh weight of sample (100 gm)

Data presented in the Tables of this investigation show the mean of the two experimental seasons

Fayoum J. Agric. Res. \& Dev., Vol. 20, No. 2, July, 2006 
RESULTS AND DISCUSSIONS

A - Vegetative growth characteristics:

1 - Plant height (cm):

Data in Table (2) indicated that plant height was significantly affected by propagation method. Terminal cuttings increased the plant height than the seedling by 1.41 and $1.32 \%$ in the two cuts of sweet basil plants.

Application of organic manure such as poultry manure significantly surpassed the farm yard manure by 0.90 and $1.23 \%$ in two cuts of the tallest plants Table (2). The results are agreement with those obtained by Jacoub (1999) on Ocimum basilicum L., Abd El-Moez et al., (1999) on fennel and coriander plants, Mohamed and Matter (2001) on Tagetes minuta L. Sakr (2001) on Mentha piperta L., and Mohamed (2006) on roselle plants.

All organic manure rates used in the study significantly increased the plant height as compared to the control plants in both cuts. At the meantime both medium level $20 \mathrm{~m}^{3} / \mathrm{fed}$. (PM) and high level $30 \mathrm{~m}^{3} / \mathrm{fed}$. (FYM) was statistically equal in producing significant plant height in the both cuts. So the highest values were obtained when Ocimum basilicum L. plants received poultry manure at rate of $20 \mathrm{~m}^{3} /$ fed from poultry manure (PM) and high rate $30 \mathrm{~m}^{3} /$ fed. farm yard manure (FYM). These results are in agreement with the findings reported by Aly (1999) on Nigella sativa L., and Abd EL-Raouf (2001), El-Gendy et al., (2001) and El-Yazal, et al., (2005) on Ocimum basilicum L.

The method of propagation such as terminal cutting combined with organic manure gave the tallest plants than the seedlings combined with organic manure in both cuts.

The most effective treatments that gave the tallest plants was terminal cutting method combined with poultry manure in both cuts.

\section{2- Number of branches per plant:}

Table (2) show that propagation method was significantly affected in number of branches/plant. The data show that the terminal cuttings gave the highest number of branches/plant of Ocimum basilicum L. plants than seedlings by about 49.69 and $42.16 \%$ in both cuts.

The differences in number of branches/plant between the two organic manure were significant for the sweet basil. Poultry manure application significantly increased the number of branches/plant than the farm yard manure by 12.82 and $10.94 \%$ in two cuts. The increase in number of branches in response to poultry manure fertilization treatments has been observed by El-Ghadban (1998) and Mansour et al., (1999) on spearmint and marjoram, Matter and Mohamed (2001) on Calendula officinalis L, ElYazal, et al., (2005) on Ocimum basilicum L. and Mohamed (2006) on roselle plants.

Application of organic manure rates significantly increased the number of branches/plant over with control plants by $20.32,34.79$ and 39.87 $\% ; 16.54,31.49$ and $35.35 \%$, respectively in both cuts. At the meantime both medium level $20 \mathrm{~m}^{3} / \mathrm{fed}(\mathrm{PM})$ and high level $30 \mathrm{~m}^{3} / \mathrm{fed}$. (PM) were statistically equal in producing significant number of branches/plant in the both cuts. So the highest values were obtained when Ocimum basilicum L. plants received poultry manure at rate of $20 \mathrm{~m}^{3} / \mathrm{fed}$. from poultry manure (PM) and high rate $30 \mathrm{~m}^{3} /$ fed. farm yard manure (FYM). These results are in agreement with the findings reported by Abd El-Raouf (2001); El-Gendy $e t$

Fayoum J. Agric. Res. \& Dev., Vol. 20, No. 2, July, 2006 
al., (2001) and El-Yazal, et al., (2005) on Ocimum basilicum L. and Mohamed and Matter (2001) on Tagetes minuta L.

The combined of terminal cuttings and organic manure gave the higher number of branches/plant as compared to the other combinations in both cuts.

The highest number of branches/plant which obtained by cultivate with terminal cutting combined with the poultry manure which surpassed the other combined in both cuts.

3 - Number of inflorescences per plant:

Table (2) indicate reported that number of inflorescences per plant significantly increased by propagation methods. Terminal cuttings increased number of inflorescences per plant over the seedling by 26.66 and $17.84 \%$ in two cuts.

Application of organic manure significantly increased number of inflorescences per plant of Ocimum basilicum L. in both cuts. Poultry manure surpassed the farm yard manure by 2.44 and $3.70 \%$ in two cuts of the number of inflorescences per plant. These results are agreement with those obtained by Jacoub (1999) on Ocimum basilicum L., Abd El-Moez et al., (1999) on fennel and coriander plants, Mohamed and Matter (2001) on Tagetes minuta L. and Mohamed (2006) on roselle plants.

All organic manure rates significantly increased the number of inflorescences per plant. The rate of increase was 3.39, 9.38 and $12.51 ; 8.52$, 14.66 and $18.07 \%$, respectively over control in both cuts. At the meantime both medium $20 \mathrm{~m}^{3} / \mathrm{fed}$. (PM), high rate $30 \mathrm{~m}^{3} / \mathrm{fed}$. (PM) and high rate 30 $\mathrm{m}^{3} /$ fed. (FYM) were statistically equal in producing significant number of inflorescences per plant in the both cuts. So the highest values were obtained when Ocimum basilicum L. plants received poultry manure at rate of 20 $\mathrm{m}^{3} /$ fed. from poultry manure (PM) and high rate $30 \mathrm{~m}^{3} / \mathrm{fed}$. farm yard manure (FYM). These results are in agreement with the findings reported by Abd ElRaouf (2001), El-Gendy et al., (2001) and El-Yazal, et al., (2005) on Ocimum basilicum L. and Mohamed and Matter (2001) on Tagetes minuta L.

The terminal cuttings combined with organic manure gave higher number of inflorescences per plant than the seedlings combined with organic manure in both cuts.

The most effective treatments that gave the higher number of inflorescences per plant was terminal cuttings combined the poultry manure.

4 - Herb fresh weight per plant ( $g$ ) :

The results presented in Table (3) show that applied of propagation methods used in this study significantly increased the herb fresh weight per plant in the two cuts. It showed that the terminal cuttings gave the highest herb fresh weight/plant of Ocimum basilicum L. plants than seedlings by 48.85 and $27.88 \%$ in both cuts.

Data revealed that the fresh weight of the herb increased gradually by organic manure treatments. The source of organic fertilizer such as poultry manure which followed by the farm yard manure fertilization increased fresh herb/plant over control by about 2.12 and $1.50 \%$ in two cuts. The results are in agreement with those obtained by El-Ghadban (1998) and Mansour et al., (1999) on spearmint and marjoram, Matter and Mohamed (2001) on Calendula officinalis L, El-Yazal, et al., (2005) on Ocimum basilicum and Mohamed (2006) on roselle plants.

Fayoum J. Agric. Res. \& Dev., Vol. 20, No. 2, July, 2006 
Table 2

Fayoum J. Agric. Res. \& Dev., Vol. 20, No. 2, July, 2006 
Increasing the levels of organic fertilizers used in the study significantly increased the fresh weight of the herb/plant by 5.67, 12.57 and $15.03 ; 3.92,9.45$ and $10.89 \%$, respectively over the control plants in both cuts. In the meantime both medium $20 \mathrm{~m}^{3}$ fed. (PM), high rate $30 \mathrm{~m}^{3} / \mathrm{fed}$. (PM) and high rate $30 \mathrm{~m}^{3} / \mathrm{fed}$. (FYM) were statistically equal in producing significant fresh weight of the herb per plant in the both cuts. So the highest values were obtained when Ocimum basilicum L. plants received poultry manure at rate of $20 \mathrm{~m}^{3} /$ fed from poultry manure (PM) and high rate 30 $\mathrm{m}^{3} /$ fed. farm yard manure (FYM). These results are in harmony with those reported by Sakr (2001) on Mentha piperta L.; Abd El-Raouf (2001), ElGendy et al., (2001) and El-Yazal, et al., (2005) on Ocimum basilicum L. and Mohamed and Matter (2001) and Somida (2002) on Tagetes minuta L.

The results in the Table (3) show that fresh weight of the herb/plant was significantly affected by interaction among to the studied factors except the interaction between methods of propagation $\mathrm{x}$ organic sources in the both cuts. The terminal cutting combined with organic manure gave the highest fresh weight of the herb/plant than the seedlings combined with organic manure in both cuts. The most effective treatment that gave higher fresh weight of herb/plant was the terminal cutting combined the poultry manure which surpassed the other combined in both cuts.

\section{5- Number of roots per plant:}

Table (3) reported that number of roots per plant significantly increased by propagation method. Terminal cuttings gave the highest number of roots per plant than the seedling by 29.00 and $23.41 \%$ in two cuts of Ocimum basilicum L.

Organic manure significantly increased number of roots per plant of Ocimum basilicum L. in both cuts. Poultry manure surpassed the farm yard manure by 4.15 and $3.14 \%$ in two cuts of the number of roots per plant. These results are in harmony with those reported by Abd El-Kader (1999) on fennel and anise.

Table (3) recorded that, all organic manure rates significantly increased the number of roots per plant by $17.56,33.36$ and $36.47 ; 8.08$, 13.05 and $15.35 \%$, respectively over control plants in both cuts. At the meantime both medium $20 \mathrm{~m}^{3} / \mathrm{fed}$. (PM), high rate $30 \mathrm{~m}^{3} / \mathrm{fed}$. (PM) and high rate $30 \mathrm{~m}^{3} / \mathrm{fed}$. (FYM) were statistically equal in producing significant number of roots per plant in the both cuts. So the highest values were obtained when Ocimum basilicum L. plants received poultry manure at medium rate of $20 \mathrm{~m}^{3} / \mathrm{fed}$ from poultry manure $(\mathrm{PM})$ and high rate $30 \mathrm{~m}^{3} / \mathrm{fed}$. farm yard manure (FYM) .

The propagation method such as terminal cuttings combined with organic manure gave higher the number of roots per plant than the seedlings combined with organic manure in both cuts.

The most effective treatments that gave the higher number of roots per plant were terminal cuttings combined the poultry manure which followed by the other combined treatments in both cuts.

In order to discuss and explain the promoting effects of both organic manure which contained macro and micro elements as shown in Table (1) on different vegetative growth characters, as well as other yield component parameters and oil production of Ocimum basilicum L. plants. It is necessary to refer to the physiological roles of the nutrients such as nitrogen and potassium in plant growth and development. Nitrogen is a constituent of most

Fayoum J. Agric. Res. \& Dev., Vol. 20, No. 2, July, 2006 
Table 3

Fayoum J. Agric. Res. \& Dev., Vol. 20, No. 2, July, 2006 
organic compounds such as amino acids, many enzymes and energy transfer materials such as chlorophyll, ADP and ATP. Growing plants must have nitrogen to form new cells and the rate of growth is proportional to the rate at which nitrogen is supplied. Photosynthesis can produce carbohydrate from $\mathrm{CO}_{2}$ and $\mathrm{H}_{2} \mathrm{O}$ but the process can not go on to the production of proteins. Thus, a severe shortage of nitrogen will effect on the processes of growth and production. The other macronutrient involved in the present study is potassium. It needed in relatively large amounts by all plants. It aids in the uptake of other nutrients and their movement within the plant. Beringer (1978) and Mengel and Kirkby (1987) reported that the role of $K$ in metabolism, growth and yield formation can be characterized by two major function: as an activator of enzymes and as $\mathrm{K}^{-}$ions are very mobile within the plant as well as within a cell are transported through biological membranes with high rate and specificity. More than 60 enzymes are known to require $\mathrm{K}^{+}$ as an activator. The high mobility of $\mathrm{K}^{+}$on photosynthesis phloem loading and phloem transport...etc. Such two nutrients are among the major essential elements needed in large quantities for all plants. They participate directly or indirectly in much important physiological process carried on simultaneously within plant cells, tissues and organs differentiation. Plant supplement with these macronutrients in soil of fertilizers is necessary because the soil is usually in deficient of them or they are not readily available for plants. Such important physiological roles enable potassium to perform its functions, which lead to an increase in various vegetative growth, yield and oil aspects. Micronutrients in sort of fertilizers are necessary because the soil is usually in deficient of them or they are not readily available for plants. Terminal cuttings of propagation is more easy methods of propagation to gave higher product because contained the maximum number of roots as shown in (Table 3 ) which increased the absorption coefficient from the soil. Therefore, Ocimum basilicum L. plants enhanced different vegetative characters and chemical component by this treated

\section{B-Chemical composition}

1 - Volatile oil percentage of herb:

Results in Table (4) showed that applied propagation was significantly affected in volatile oil percentage/plant. It was clear from the results that terminal cuttings gave the highest volatile oil percentage/plant of Ocimum basilicum L. plants than seedlings by 2.78 and $2.80 \%$ in both cuts.

The differences in volatile oil percentage/plant between the two organic manure were significant for the sweet basil. Poultry manure application significantly increased the volatile oil percentage/plant than the farm yard manure by 1.85 and $1.87 \%$ in two cuts. The increase in volatile oil percentage/plant in response to poultry manure fertilization treatments has been observed by Abd El-Raouf (2001), El-Gendy et al., (2001) and ElYazal, et al., (2005) on Ocimum basilicum L. and Mohamed and Matter (2001) and Somida (2002) on Tagetes minuta L.

Application of organic manure rates significantly increased the volatile oil percentage per plant as compared to the control plants by $9.57,25.53$ and $28.72 ; 10.75,25.80$ and $29.03 \%$, respectively in both cuts. In the meantime both medium $20 \mathrm{~m}^{3} / \mathrm{fed}$. (PM), high rate $30 \mathrm{~m}^{3} / \mathrm{fed}$. (PM) and high rate 30 $\mathrm{m}^{3} /$ fed. (FYM) were statistically equal in producing significant oil percentage per plant in the both cuts. So the highest values were obtained when Ocimum basilicum L. plants received poultry manure at rate of $20 \mathrm{~m}^{3} / \mathrm{fed}$. from

Fayoum J. Agric. Res. \& Dev., Vol. 20, No. 2, July, 2006 
EFFECT OF PROPAGATION METHODS AND ORGANIC

poultry manure (PM) and high rate $30 \mathrm{~m}^{3} /$ fed. farm yard manure (FYM), Table (4). These results are in agreement with the findings reported by Abd El-Raouf (2001), El-Gendy et al., (2001) and El-Yazal, et al., (2005) on Ocimum basilicum L. and Mohamed and Matter (2001) and Somida (2002) on Tagetes minuta L.

The combined with terminal cutting and organic manure gave the higher volatile oil percentage per plant compared to the other combined in both cuts.

The highest volatile oil percentage per plant which obtained by the cultivate with terminal cutting combined with the poultry manure which surpassed the other combined in both cuts.

2 - Volatile oil yield of herb per plant $(\mathrm{ml})$ :

The data listed in Table (4) show that volatile oil yield/plant in the herb of Ocimum basilicum L. plant was significantly affected by different propagation methods. It took similar trend to that of oil percentage. A gradual rise in the yield of volatile oil per plant accompanied by the different propagation methods. It was clear from the results that terminal cuttings gave the highest volatile oil yield/plant of Ocimum basilicum L. plants than seedlings by 53.31 and $31.15 \%$ in both cuts.

Data in Table (4) indicated that, the difference in volatile oil yield/plant between the two organic manure was significant for the sweet basil. Poultry manure application significantly increased the volatile oil yield/plant than the farm yard manure by 4.18 and $3.31 \%$ in two cuts. The increase in volatile oil percentage/plant in response to poultry manure fertilization treatments has been observed by Mohamed and Matter (2001) and Somida (2002) on Tagetes minuta L. and Sakr (2001) on spearmint plants.

A gradual rise of organic manure rates significantly increased the volatile oil yield per plant as compared to the control plants by $15.81,41.54$ and $48.16 ; 14.97,37.70$ and $43.05 \%$, respectively in both cuts. In the meantime both medium $20 \mathrm{~m}^{3}$ fed. (PM), high rate $30 \mathrm{~m}^{3} / \mathrm{fed}$. (PM) and high rate $30 \mathrm{~m}^{3} / \mathrm{fed}$. (FYM) were statistically equal in producing significant volatile oil yield in the both cuts. So the highest values of volatile oil yield were obtained when Ocimum basilicum L. plants received organic manure at rates of $20 \mathrm{~m}^{3} /$ fed from poultry manure $(\mathrm{PM})$ or high rate $30 \mathrm{~m}^{3} / \mathrm{fed}$. from farm yard manure (FYM), Table (4). These results are in agreement with the findings reported by Abd El-Raouf (2001), El-Gendy et al., (2001) and ElYazal, et al., (2005) on Ocimum basilicum L. and Mohamed and Matter (2001) and Somida (2002) on Tagetes minuta L.

Table (4) recorded that, volatile oil yield per plant was significantly affected by interaction among the studied factors except the interaction between methods of propagation $\mathrm{x}$ organic levels, in the both cuts. The terminal cutting combined with organic manure gave the highest volatile yield per plant than the seedlings combined with organic manure in both cuts. The most effective treatments that gave the highest volatile oil yield per plant were the terminal cuttings combined the poultry manure that surpassed the other combined in both cuts.

\section{3-Volatile oil yield of herb per feddan (Liter):}

Table (4) clearly show that total volatile oil yield of herb per feddan as affected by different applied propagation methods, took almost the same trend observed for total volatile oil yield of herb per plant. Cultivated

Fayoum J. Agric. Res. \& Dev., Vol. 20, No. 2, July, 2006 
Table 4

Fayoum J. Agric. Res. \& Dev., Vol. 20, No. 2, July, 2006 
Ocimum basilicum L. plants with the cuttings resulted in highly significant promotion in the two cuts. Moreover, gradually significant increase in such product was observed due to the terminal cuttings the increase reached about 53.31 and $31.15 \%$ in the first and second cuts, respectively over the seedlings

The obtained results in Table (4) also revealed that the main effect of organic manure fertilization on the volatile oil yield of herb per feddan was statistically significant. All used poultry manure significantly surpassed the farm yard manure treatment in the two cuts by rate 4.18 and $3.31 \%$. These results took the same trend with Mohamed and Matter (2001) and Somida (2002) on Tagetes minuta L. and Sakr (2001) on Mentha piperta L.

Organic manure rates took almost the same trend observed for total volatile oil yield of herb per plant. Volatile oil yield per feddan significantly increased over control plants by 15.81, 41.54 and 48.16; 14.97, 37.70 and $43.05 \%$, respectively in both cuts. In the meantime both medium $20 \mathrm{~m}^{3}$ fed. $(\mathrm{PM})$, high rate $30 \mathrm{~m}^{3} / \mathrm{fed}$. (PM) and high rate $30 \mathrm{~m}^{3} / \mathrm{fed}$. (FYM) were statistically equal in producing significant volatile oil yield in the both cuts. So the highest values of volatile oil yield were obtained when Ocimum basilicum L. plants received organic manure at rates of $20 \mathrm{~m}^{3} / \mathrm{fed}$. from poultry manure (PM) or high rate $30 \mathrm{~m}^{3} / \mathrm{fed}$. from farm yard manure (FYM). These results are in agreement with the findings reported by Abd El-Raouf (2001), El-Gendy et al., (2001) and El-Yazal, et al., (2005) on Ocimum basilicum L. and Mohamed and Matter (2001) and Somida (2002) on Tagetes minuta L.

The data listed in Table (4) show that volatile oil yield per feddan in the herb of Ocimum basilicum L. plants took almost the same trend observed for total volatile oil yield of herb per plant. It was significantly affected by interaction among the studied factors except the interaction between methods of propagation $\mathrm{x}$ organic levels, in the both cuts. The terminal cutting combined with organic manure gave the higher volatile oil yield per plant than the seedlings combined with organic manure in both cuts. The most effective treatments that gave the volatile oil yield per plant was the terminal cuttings combined the poultry manure which surpassed the other combined in both cuts.

4 - Photosynthetic pigments content (mg / 100g):

Table (5) reported that photosynthetic pigments (chlorophyll a, b and caroteniods) contents in the leaves significantly increased by applied propagation. Terminal cuttings increased chlorophyll a, b and caroteniods contents over the seedlings by 1.80 and $2.03 ; 5.44$ and $6.43 ; 9.68$ and $8.96 \%$, respectively in two cuts.

The same Table (5) show that application of organic manure significantly increased chlorophyll a, b and caroteniods contents of Ocimum basilicum L. in both cuts. Poultry manure surpassed the farm yard manure by 5.87 and $2.54 ; 8.11$ and $3.52 ; 10.94$ and $2.90 \%$, respectively in two cuts of chlorophyll a, b and caroteniods contents. The results are agreement with those obtained by Mohamed and Matter (2001) and Somida (2002) on Tagetes minuta L., Matter and Mohamed (2001) Calendula officinalis L., Sakr (2001) Mentha piperta L. and Mohamed (2006) on roselle.

Also, data in same Table (5) revealed that chlorophyll a, b and caroteniods contents was significantly affected by organic manure rates. Chlorophyll a, b and caroteniods contents significantly increased by treated

Fayoum J. Agric. Res. \& Dev., Vol. 20, No. 2, July, 2006 
with poultry manure rates than farm yard manure in the same. The highest values of chlorophyll a, b and caroteniods content were obtained when Ocimum basilicum L. plants received organic manure at rates of 20 or 30 $\mathrm{m}^{3} /$ fed from poultry manure (PM) and high rate $30 \mathrm{~m}^{3} / \mathrm{fed}$. farm yard manure (FYM). These results are in agreement with the findings reported by Abd EL-Raouf (2001) and El-Gendy et al., (2001) on Ocimum basilicum L., Mohamed and Matter (2001) on Tagetes minuta L. and Sakr (2001) Mentha piperta L. plants.

Table (5) show that the terminal cuttings combined with organic manure gave the best chlorophyll a, b and caroteniods contents than the seedlings combined with organic manure in both cuts.

The most effective treatments that gave the best chlorophyll $a, b$ and caroteniods content were terminal cuttings combined the poultry manure which surpassed the other combined in both cuts.

5- Mineral contents ( $N, P$ and $K)$ :

The result in Table (6) show mineral contents such as nitrogen, phosphorus and potassium percentages contents in the herb significantly increased by applied propagation. Terminal cuttings increased mineral contents $(\mathrm{N}, \mathrm{P}$ and $\mathrm{K})$ over the seedlings by 5.40 and $7.33 ; 7.09$ and 10.40 ; 6.17 and $6.48 \%$, respectively in two cuts.

Table (6) show that application of organic manure significantly increased mineral contents (N, P and K) of Ocimum basilicum L. in both cuts. Poultry manure surpassed the farm yard manure by 7.04 and $8.87 ; 3.78$ and 2.97; 5.68 and $7.66 \%$, respectively in two cuts of mineral contents $(\mathrm{N}, \mathrm{P}$ and K). The results are agreement with those obtained by Mohamed and Matter (2001) on Tagetes minuta L., Matter and Mohamed (2001) Calendula officinalis L., El-Yazal, et al., (2005) on Ocimum basilicum L. and Mohamed (2006) on roselle plants.

Mineral contents (N, P and K) significantly increased by treated with poultry manure rates than farm yard manure. In the meantime both medium $20 \mathrm{~m}^{3}$ /fed. (PM), high rate $30 \mathrm{~m}^{3} /$ fed. (PM) and high rate $30 \mathrm{~m}^{3} /$ fed. (FYM) were statistically equal in producing significant mineral contents $(\mathrm{N}, \mathrm{P}$ and $\mathrm{K})$ in the both cuts. So from economical sides the highest mineral contents (N, P and K) were obtained when Ocimum basilicum L. plants received organic manure at rates of $20 \mathrm{~m}^{3} / \mathrm{fed}$. from poultry manure (PM) or high rate $30 \mathrm{~m}^{3} /$ fed. from farm yard manure (FYM).

Table (6) reported that the terminal cuttings combined with organic manure gave the best mineral contents (, , P and $\mathrm{K}$ ) than the seedlings combined with organic manure in both cuts.

The most effective treatments that gave the best mineral contents $(\mathrm{N}$,

$\mathrm{P}$ and $\mathrm{K}$ ) were terminal cuttings combined the poultry manure which surpassed the other combined in both cuts Table (6).

Fayoum J. Agric. Res. \& Dev., Vol. 20, No. 2, July, 2006 
Table 5

Fayoum J. Agric. Res. \& Dev., Vol. 20, No. 2, July, 2006 
Faisal M.A. Matter and Esam G. Somida

Table 6

Fayoum J. Agric. Res. \& Dev., Vol. 20, No. 2, July, 2006 
6 - Total carbohydrates content (mg/g D.W) :

Data in Table (7) clearly showed that total carbohydrates content gradually increased affected by different applied propagation methods. The maximum increases in total carbohydrates were obtained by cultivated with terminal cuttings and followed by the seedlings in both cuts.

Organic fertilization caused a significant increase in total carbohydrates content as shown in Table (7). The increase in such constituent was gradual and parallel to the fertilized by poultry manure than the farm yard manure. The results are agreement with those obtained by Mohamed and Matter (2001) on Tagetes minuta L., Matter and Mohamed (2001) Calendula officinalis L., ElYazal, et al., (2005) on Ocimum basilicum L. and Mohamed (2006) on roselle plants.

The data listed in Table (7) showed that increasing the levels of organic fertilizers used in the study significantly increased the total carbohydrates content by $2.08,5.98$ and $7.01 ; 1.86,5.51$ and $6.68 \%$, respectively over control plants in both cuts. In the meantime both medium $20 \mathrm{~m}^{3} / \mathrm{f} \mathrm{ed}$. (PM), high rate 30 $\mathrm{m}^{3} / \mathrm{fed}$. (PM) and high rate $30 \mathrm{~m}^{3} / \mathrm{fed}$. (FYM)were statistically equal in producing significant total carbohydrates content in the both cuts. So the highest values were obtained when Ocimum basilicum L. plants received poultry manure at rate of $20 \mathrm{~m}^{3} / \mathrm{fed}$ from poultry manure (PM) and high rate $30 \mathrm{~m}^{3} / \mathrm{fed}$. farm yard manure (FYM). These results are in harmony with those reported by Abd El-Raouf (2001) and El-Gendy et al., (2001) on Ocimum basilicum L.

Table (7) reported that the terminal cutting combined with organic manure gave the best total carbohydrates content than the seedlings combined with organic manure in both cuts .

The most effective treatments that gave the best total carbohydrates content was terminal cuttings combined with poultry manure which surpassed the other combined in both cuts.

Table 7

Fayoum J. Agric. Res. \& Dev., Vol. 20, No. 2, July, 2006 
In conclusion, it could be recommended to use terminal cuttings combined with poultry manure at rate of $20 \mathrm{~m}^{3} / \mathrm{fed}$. or farm yard manure at rate of $30 \mathrm{~m}^{3} / \mathrm{fed}$. to produce sweet basil plants having the tremendous growth rates and high volatile oil content in the same time to reduce the hazard of soil pollution as a result of using chemical fertilizers in agricultural production.

\section{REFERENCES}

Abd El-Kader, A.A. (1999): Nitrogen nutrition of fennel (Foeniculum vulgaris Mill) and anise (Pimpinella anisum L.) and their effects on growth and essential oil contents. M.Sc. Thesis Fac. Agric., Assiut Univ.

Abd El-Moez, M.R.; Saleh, A.L. and Wanas, Sh.A.H. (1999): Influence of some organic compost on yield, nutrients uptake and consumptive use of fennel and coriander plants and some soil properties. J. Agric. Sci., Mansoura Univ., 24(10): 6237-6253.

Abd El-Raouf; R.M.S. (2001): Production of sweet basil (Ocimum basilicum L.) in the new reclaimed lands under different levels of biofertilizers and plant density. M.Sc. Thesis Fac. Agric., Ain Shams Univ.

Adams, J. (2003): Interview by Michele Meyers. June 5.

Aly, M.S. (1999): Effect of FYM alone or combined with NPK on Nigella sativa L. plants. J. Agric. Sci. Mansoura Univ., 24(12): 75677577.

A.O.A.C. (1995): Official Methods of Analysis of the Association Official Agricultural chemist, Franklin Station. Washington, D.C.B.

Aruna, K. and Sivaramakrishnan, V. (1992): Anticarcinogenic effects of some Indian plant products. Food chem. toxicology. 30: 953956.

Beringer, H. (1978): Functions of potassium in plant metabolism with particular reference of yield pp. 185-202. In G. S. Sekhon (ed.) Potassium in soils and crop. New Delhi. India: Potash Res. institute of India; (C.F. Fertilizer Abst. (2),1981).

Blumenthal, Mark, Ed. (1998): The complete German Commission E monographs: therapeutic guide to herbal medicines. Austin, TX: American Botanical Council. (HSA Library)

British Pharmacopoeia (1983): The pharmaceutical press 17. Bloomsbury, square London W.C.I.

El-Gendy, S.A.; Hosni, A. M.; Ahmed, S.S. and Saber, R.M. (2001): Sweet basil (Ocimum basilicum L.) productivity under different organic fertilization and inter-plant spacing levels in a newly reclaimed land in Egypt. Ann. Agric. Sci., Ain Shams Univ., 46 (1): 319-338.

El-Ghadban, E.A.A.E. (1998): Effect of some organic and chemical composition of spearmint and marjoram plants. Ph.D. Thesis Fac. Agric., Cairo Univ.

El-Yazal, M.A.; Sawsan, A.S. El-Yazal and Somida. E.G. (2005): Effect of soil application of poultry manure, soil and foliar spray of potassium sources on growth and chemical constituents of Ocimum basilicum L., sweet basil. Egypt J. of Appl. Sci.,20 (12B) : 485- 508 .

Fayoum J. Agric. Res. \& Dev., Vol. 20, No. 2, July, 2006 
EFFECT OF PROPAGATION METHODS AND ORGANIC

Gomes, K.A. and Gomes, A.A. (1983): Statistical Analysis Procedure of Agricultural Research. John Wiley and Sons, New York, pp. 2530.

Herbert, D.; Phipps, P.J. and Strange, R.A. (1971): Determination of Total Carbohydrate, Methods in Microbiology, 5B, Academic Press London, pp 209-344.

Hornok, L. (1992): Cultivation and Processing of Medicinal Plants. Johen Wiley \& Sons, New York, pp. 220.

Hussein, A.; Virmani, O.P.; Sharam, Kumar, A. and Misra, L.N. (1988): Major Essential oil -Bearing Plants of India Central Institute of Medicinal and Aromatic Plants, Lucknow, India pp.6.

Jacoub, R.W. (1999): Effect of some organic and nonorganic fertilizers on growth, oil yield and chemical composition of Ocimum basilicum L. and Thymus vulgares L. plants. Ph.D Thesis Fac. Agric., Cairo Univ.

Mansour, H.A.; El-Maadawy, E.I. and El-Ghadban, E.A. (1999): Organic and Inorganic fertilization of spearmint and marjoram. Bull. Fac. Agric. Cairo Univ., 1: 226-239.

Matter, F.M.A. and Mohamed, S.A. (2001): Botanical studies on Calendula officinalis L. plants as affected by organic and inorganic fertilizers under newly reclaimed soil condition. Fayoum J. Agric. Res. \& Dev., 15(2): 50 - 65

Mengel, K. and Kirkby, E.A. (1987): Principles of Plant Nutrition. International Potash Institute. Switzerland, $4^{\text {th }}$ edition.

Mohamed, S.A. (2006): A comparison between the effect of different sources of organic and mineral fertilizers on growth, anatomical structure, yield and chemical composition of roselle (Hibiscus sabdariffia L.) plants. The Second Conference on Farm Integrated Pest Management 16-18 Jan .2006 pp: 99-111 in Fac. Agric., Fayoum Univ.

Mohamed, S.A. and Matter, F.M.A. (2001): Effect of ammonium nitrate and organic fertilizers on growth, volatile oil yield and chemical constituents of marigold (Tagetes minuta L.) plant. Fayoum J. Agric., Res. \& Dev., 15 (1): 95-107.

Nyarko, A.K. (2002): Extract of Ocimum canum lowers blood glucose and facilitates insulin release by isolated pancreatic beta-islet cells. Phytomedicine. May; 9 (4): 346-51.

Opalchenova, G. and Obreshkova, D. (2003): Comparative studies on the activity of basil-an essential oil from Ocimum basilicum L.against multidrug resistant clinical isolates of the genera Staphylococcus, Enterococcus and Pseudomonas by using different test methods. J Microbiol Methods. Jul; 54(1): 105-10.

Page, A.I.; Miller, R.H. and Keency, D.R. (eds) (1982): Methods of soil Analysis Part II. Chemical and Microbiological Methods. $2^{\text {nd }}$ ed Am. Soc. Agron., Madison, Wisconsin U.S.A

Sakr, W.R.A.S. (2001): Effect of some organic and inorganic fertilizers on Mentha piperta. M.Sc. Thesis Fac. Agric., Cairo Univ.

Somida, E.G. (2002): Effect of organic manure, nitrogen and potassium fertilization on growth, flowering and chemical constituents of marigold plants (Tagetes minuta L.,) Ph.D. Thesis Fac. Agric., Fayuom, Cairo Univ.

Fayoum J. Agric. Res. \& Dev., Vol. 20, No. 2, July, 2006 
Faisal M.A. Matter and Esam G. Somida

Welburn, A.R. and Lichtenthaler, H. (1984): Formula and program to determine total caroteniods and chlorophyll a and $b$ of leaf extracts different solvents InAdvances in photosynthesis Research (Sybesma C.Ed.) Vol., II pp. 9- 12.Mortinus Njihoff Dr.W. Junk publishers, the Hague.

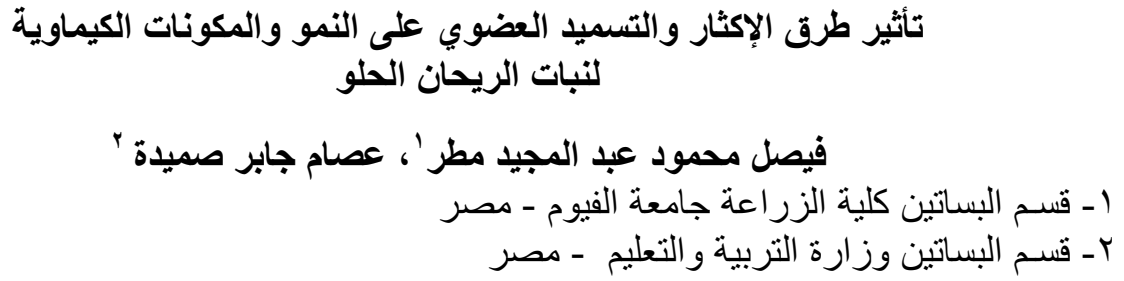

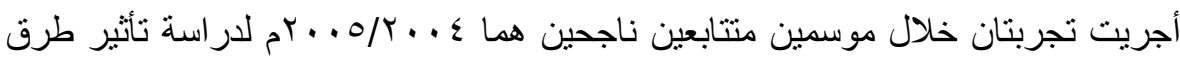

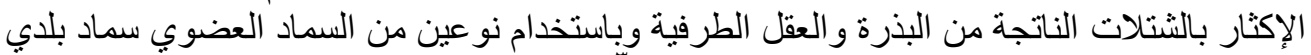

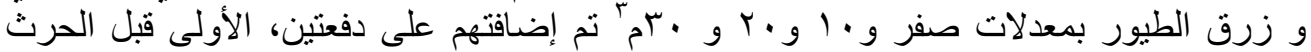

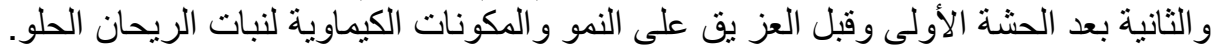

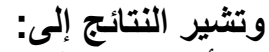

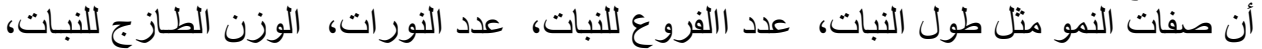

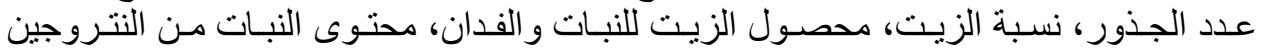

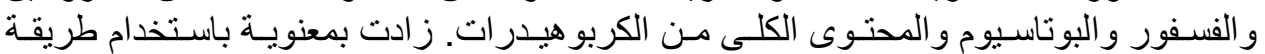

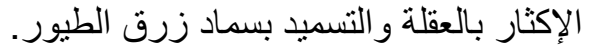

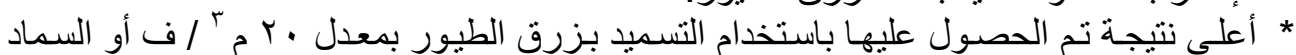

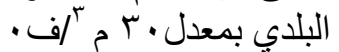

* الإكثار بالعقل الطرفية مع التسميد العضوي أعطى أحسن نتيجة من الإكثار بالثتنات الناتجة من

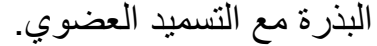

* الإكثار بالعقل الطرفية مع التسميد بزرق الطيور أعطى أحسن نتيجة من التفاعلات الأخرى

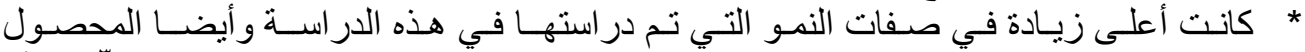

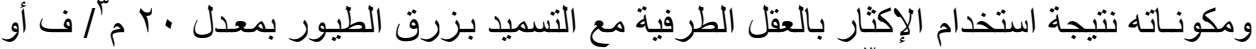

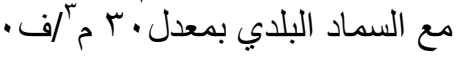

Fayoum J. Agric. Res. \& Dev., Vol. 20, No. 2, July, 2006 